An Cowan Dixon
Spechives

Belden Center Monographs
Harding University

Scholar Works at Harding

The Belden Center for Private Enterprise

1992

\title{
Christianity and Economics, 1992
}

David Tucker Ph.D.

Follow this and additional works at: https://scholarworks.harding.edu/belden-monographs

Part of the Economics Commons

\section{Recommended Citation}

Tucker, D. (1992). Christianity and Economics, 1992. Retrieved from https://scholarworks.harding.edu/ belden-monographs/55

This Book is brought to you for free and open access by the The Belden Center for Private Enterprise Education at Scholar Works at Harding. It has been accepted for inclusion in Belden Center Monographs by an authorized administrator of Scholar Works at Harding. For more information, please contact scholarworks@harding.edu.

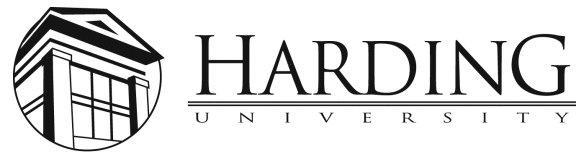



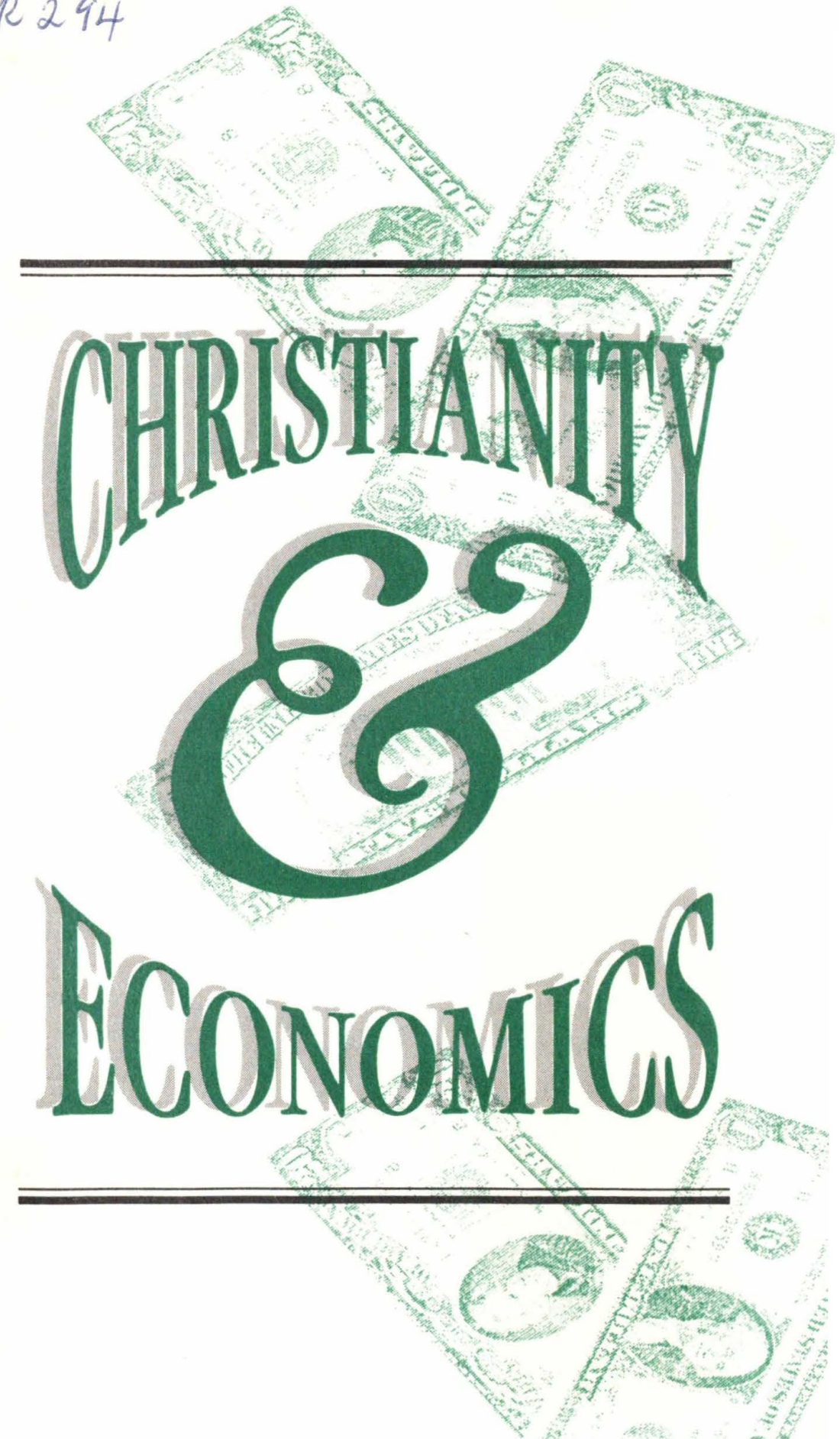

by

David Tucker, Ph.D. Dean, School of Business Harding University Searcy, Arkansas

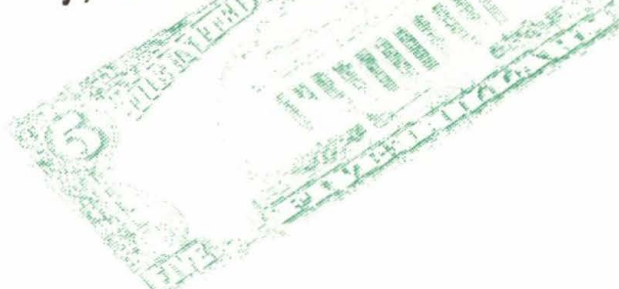


A

Commemorative Issue

of

The Entrepreneur

a quarterly journal

of the

Belden Center for

Private Enterprise Education

All rights reserved

Copyright November, 1992

Requests for permission to reproduce this publication should be addressed in writing as follows:

Dr. David Tucker, Dean School of Business Harding University

Box 774

Searcy, Arkansas 72149-0001

(501) 279-4240 


\section{TABLE OF CONTENTS}

CHRISTIANITY AND ECONOMICS--

An Introduction ............... 1

I. ADAM: THE FIRST ECONOMIST ....... 3

Scarcity and Adam ........... 4

Means and Ends $\ldots \ldots \ldots \ldots \ldots \ldots$

II. EXERCISING DOMINION . . . . . . . . 8

Property Rights and Wealth .........9

Mercantilism Emerges . . . . . . . . . 10

Capitalism vs. Socialism . . . . . . . . . 12

Socialism and the First Century ...... 13

III. FAMILY THROUGH THE EYES OF

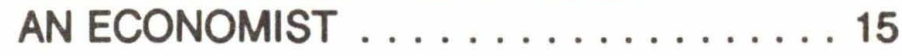

Capitalism and Socialism .......... 15

The Family and Capitalism . . . . . . . . 18

The Family and Socialism . . . . . . 20

Creeping Socialism . . . . . . . . . 21

IV. THE ECONOMICS OF SIN $\ldots \ldots \ldots \ldots 23$

The Moral Link . . . . . . . . . . . . . 24

The Concentration of Power . . . . . . . 2 26

V. IN THE IMAGE OF GOD: FREEDOM . . . 28

Trade-Offs and Choices . . . . . . . . 29

Economic Application . . . . . . . . 30

Socialism Revisited . . . . . . . . . . 30

Capitalism amd the Individual . . . . . . 31 



\title{
CHRISTIANITY AND ECONOMICS
}

\section{An Introduction}

\author{
Dr. David Tucker \\ Dean, School of Business \\ Harding University \\ Searcy, Arkansas
}

Certainly we know from reading our Bibles that the personal economic situation of any individual does not determine his or her salvation. The essence of salvation comes through a realization of sin, a confession of faith, an acceptance of baptism, and living a new life in Christ. Salvation is not determined by free enterprise or the size of one's bank account, but they undoubtedly have a great impact on the Christian's life.

Salvation can be found under political freedom or tyranny, under economic prosperity or poverty, under social stability or anarchy. While being thankful for the freedoms we enjoy in the United States and praying for the extension of freedom in the former Soviet Union and all parts of the earth, we should be even more thankful that salvation is not limited to any particular political or economic system. God's power cannot be limited by governmental edict or economic power. In fact, it is only by His grace that governments exist and fortunes are accumulated.

Therefore, realizing that God's power and the salvation of souls transcends economics and politics, we also acknowledge that economics does have a significant effect on what we are able to do and how we conduct our Christian walk through life. It is only through our prosperity that we are able to print Bibles, educate our children, build our buildings, send missionaries, provide for our families, and better endure the thorns and thistles of life.

Economics is a vital part of every Christian's life. It has a dominating role in how we conduct our affairs, and I personally believe it is too important a subject to be left to non-believers. As Christians, we must study economics to insure the voice of Christ is heard in this critical area.

While salvation transcends economics and politics, once we have accepted Christ as Savior, we are faced with living as Christ would have us live. At the 
same time, we must earn a living and feed our families. Even though we should "render to Caesar the things that are Caesar's," another command should be remembered: Christians are to be salt and light to the world. We should be active in making sure that Christian principles are used in forming the political, economic and social systems under which we live. To do otherwise would be to abandon an important part of every life to non-Christian thinking and practice.

It is not the purpose of this series of articles on "Christianity and Economics" to let our economics guide our Christianity. The purpose of this series is to let Christ and Scripture form our way of thinking about economics. We must first search God's word, and then apply those principles we find in God's word to our economic situations.

There are two different approaches to a Christian view of economics. The first is an institutional approach, and the second is a personal approach. The institutional approach studies the structure of the economic system as a whole. In other words, the institutional approach looks at the economic structure of capitalism versus socialism, private property versus public ownership of property, and Keynesian economics versus classical thought--to name just three concepts discussed by economists.

The personal approach, on the other hand, is a study of how an individual behaves within the existing institutions of the current economy. In other words, given that we live in a largely capitalistic economy, the personal approach studies how an individual behaves within the current institutions of free enterprise that exist in the United States. This publication will discuss both approaches, but will concentrate more often on the institutional approach.

The above comments serve as an introduction to a series of articles by this author. These articles first ran in the June-August, 1992 editions of the Gospel Advocate and are reprinted herein with permission. As we examine several aspects of economics as economics relates to Christianity, we will begin by focusing on the introduction of economics into the world through the sin of Adam and Eve. 


\section{ADAM: THE FIRST ECONOMIST}

A careful reading of Genesis reveals the exact moment when Adam became the first economist. After Adam and Eve sinned, God announced the punishment Adam would face (Gen. 3:17-19):

And to Adam he said, "Because you have listened to the voice of your wife, and have eaten of the tree of which I commanded you 'You shall not eat of it,' cursed is the ground because of you; in toil you shall eat of it all the days of your life; thorns and thistles it shall bring forth to you; and you shall eat the plants of the field. By the sweat of your brow you shall eat bread till you return to the ground, for out of it you were taken; you are dust, and to dust you shall return."

The science of economics was born. As a result of the curse upon Adam, the soil would no longer be the giving, fruitful ground it once had been. It would only be through labor and effort that Adam (and by generational extension, the rest of us as well) would be able to put food on the table.

It is interesting to note here that work was a part of Adam's life even before the fall. Genesis 2:15 states, "The Lord God took the man and put him in the Garden of Eden to work it and take care of it." In other words, the curse of Adam was not that he was condemned to a life of work. Adam worked before the fall. The curse of Adam was that work would be frustrating and difficult because the ground would no longer be so giving. Work is not a curse. In fact, God Himself was a worker. One of the ways man is created in the image of God is that man was created for work since God was a worker. Genesis 2:2-3 attests to the fact that God was a worker:

By the seventh day God had finished the work he had been doing; so on the seventh day he rested from all his work. And God blessed the seventh day and made it holy, because on it he rested from all the work of creating that he had done.

So we come to understand that the curse of Adam was not work, but frustration. The weeds would always grow faster than the fruit. And even though there are fewer farmers today (according to Department of Agriculture statistics there are only 314,000 commercial farms in the United States with sales greater than $\$ 100,000)$, everyone knows a 
garden left untended grows more weeds than tomatoes. Any business will go downhill without the constant, caring attention of workers and owners. This was the way God made it. The science of economics was born, and it is still with us today, just the way God intended it.

Economists and preachers do not always communicate very well, and one reason is they use different jargon. They speak a different language. Although often saying the same thing, they use different words and so they think the other is saying something different. But often they are not. If someone familiar with both languages does some interpreting, then agreement often comes about.

\section{Scarcity and Adam}

So it is with the concept of Adam and $\sin$ and weeds and fruit. A preacher understands this point from a theological point of view. The reality of Adam's sin caused God to curse Adam with the punishment of sweat and the fact that weeds will perpetually grow faster than fruit. An economist says the same thing, but an economist starts his analysis not with the theology of the fall, but by simply assuming that scarcity exists.

Saying that scarcity exists is not nearly as interesting as telling the story of Adam and Eve, the serpent, the fall and the curse. The bedtime stories economists tell their children are not nearly as interesting as Bible bedtime stories. But this assumption (scarcity exists) is the economic equivalent of the curse of Adam.

We need to pause a moment and expand on the fundamental definition of economics so there is no misunderstanding. While scarcity is a good shorthand definition of economics, a frequently used definition is: Economics is the study of the allocation of limited resources among unlimited wants.

Let's consider this definition more carefully. To understand it one must consider the three main parts: (1) unlimited wants, (2) limited resources, and (3) allocation. Unlimited wants is a commentary on human nature. We all want to acquire more. This is not an assumption a Christian would like to make, but one must deal with the world as it is, not as one wishes it to be. The reality of the world is that most 
are not Christians, and these non-Christians are very acquisitive in nature.

Even those of us who try to live the Christian life fall prey to our sinful nature. We fail to mirror Paul's example of being content wherever he found himself. All of us (Christians and non-Christians alike) enjoy the accumulation of things, and when one considers that there are about 5 or 6 billion people in the world, then the sum of all human wants can safely be assumed to be limitless.

The second part of the definition, limited resources, relates directly to Adam. While in the Garden of Eden, the soils were giving and fruitful, but once the curse was in place, the resources Adam had to provide for the wants and needs of life were scarce and limited. The resource of food could no longer be picked off trees in abundance. The resource of clothing was now necessary and had to be acquired. The resource of shelter was necessary to house a growing family. While Adam had to work before the fall, after the fall providing the basic needs of life was a real problem. Limited resources collided with unlimited wants.

We now turn to the final part of the definition: allocation. With a growing population faced with limited resources and growing, limitless wants, there must be some means developed for allocating or distributing the scarce resources that do exist. In economic jargon, since scarcity exists, the limited resources we do have must somehow be allocated among competing wants. Those who want are always more numerous than those who have, so a system must be in place to do the allocating. This, then, is the purpose of economics: to study the different systems which can be put in place to allocate limited resources among unlimited wants.

The fact that scarcity exists mandates that there will be competition for resources. While Adam and his children did not have to worry a great deal about competition for available land (there was a great deal of land then in comparison with the number of people living), competition for space is a fact of life for those of us who live in more crowded societies. Some argue that we should reduce competition and try to cooperate more, but this idealistic statement ignores the fact that competition is the result of scarcity, and God imposed scarcity on society with the fall of Adam. 


\section{Means and Ends}

Since competitive behavior is the result of scarcity and cannot be wished away, the real question then becomes: How can we organize society so that competitive behavior is channeled into productive activities rather than destructive activities? Is there a way to create a set of rules so that competition is good rather than bad?

There are actually two extremes when one talks about the rules that should govern society. The first extreme of rules is that there are no rules: anarchy. When society has no rules to govern the behavior of its members, then anarchy reigns, or more correctly, there will be the rule of the strong. Those with the most physical power will govern everyone else. There are not many adherents to this philosophy.

The second extreme is a smothering state, a totalitarian state where the rules are detailed and omnipresent. In this type of society there are rules where one lives, where one works, what one can earn, where one's children go to school, and most every other aspect of personal life. The totalitarian state is not desirable because of its complete lack of freedom. In fact freedom does not exist in anarchy (because the strong tell the weak what to do) or in totalitarianism (because the state tells everyone what to do). Upon reflection, there is little difference between the two extremes.

The problem in constructing an economic and social system is to create an orderly society that at the same time respects personal freedom. There have been two attempts to do so, and these go by the generic names of capitalism and socialism.

While the Lord instituted scarcity in the world through the curse placed on Adam, the Lord did not provide similar guidance in His choice of economic systems. It would have been convenient if the Lord had given an 11th commandment stating His preference for one or the other, but He simply did not give us direct and unambiguous guidance as to His choice of an economic system. While one may certainly argue that one or the other is more consistent with Christianity, there are enough arguments on both sides to make a dogmatic declaration of God's preference impossible. 
My personal belief is that the Lord is more concerned with personal behavior than $\mathrm{He}$ is with economic systems. He cares more about personal integrity and stewardship than $\mathrm{He}$ does about the systems of capitalism or socialism. But having said that, I do not think it is improper for us to look in our Bibles to discover if one system is more consistent with Christian principles than the other system. And in order to make such a judgmental comparison, we must take the time to lay some groundwork in the differences between the two systems.

While there are many differences between capitalism and socialism, in the final analysis there is one that stands out as the most important. This difference of first importance has to do with the ownership of resources. Simply put, capitalistic societies allow for private ownership of resources, but socialistic societies allow only communal ownership of resources.

Once the type of ownership is established in a society, the remainder of the issues more or less naturally fall into place. Because this issue is so important, it is the sole subject of our next essay in this series on economics and Christianity. 


\section{EXERCISING DOMINION}

As Adam exited the Garden of Eden, he faced a very uncertain future. With the angel standing guard over the entrance, there was no going back. He faced a world that was difficult, because God no longer walked with Adam in the cool of the afternoon. Adam was on his own. He had more decisions to make, and God was not present as much as $\mathrm{He}$ was before Adam sinned.

In spite of the necessity of frustrating work by Adam after he had been driven from the Garden of Eden, Adam still did not face many of the problems we face today. In order to survive, Adam was essentially forced to deal with subsistence agriculture and hunting. Adam did not need to worry about competition for hunting land or the price of crops. A cash economy did not exist. However, as the population of the earth expanded, economic and social relations became more complex. The Lord, of course, was very displeased with the direction that man took and eventually destroyed with water all the things man had made up until that time.

After the flood, life expanded again, and apparently prosperity was the order of the day. Men and women, united by a common language and culture, were able to achieve a level of technology and a standard of living that allowed them to dream of building a tower to heaven. But the dream of building the tower ended when the Lord was displeased with their impertinence, confused their languages, and made the subject of international economics inevitable.

It would have been easier for Adam, Noah and their seed if God had specified the economic system Adam should install outside of the Garden. It would be easier for all of us if God had specified in His Word what type of economic arrangements are most in keeping with His wishes. But God did not, and until the Lord comes again men will continue to debate, argue, and even fight over the proper economic arrangements for a complex society.

Since the fall of Adam, the flood, and the tower of Babel, many different types of economic systems have been tried. Tribalism and feudalism are but two of the many that have been tried and eventually abandoned by society through the ages. Even though there have been many economic systems 
down through the ages, it is very easy to identify an economic system.

An economic system reveals itself through one primary, fundamental characteristic: the ownership of property. How does the economic system handle the ownership, use, management and disposition of property? Once this fundamental question is handled, most answers fall into place. Once the question of property ownership is defined, society has largely decided how it will fulfill God's command to exercise dominion over the earth.

\section{Property Rights and Wealth}

Before getting into the details of ownership, let us first define what is meant by property. The term property is not limited to land. Although property certainly includes land, the term should be defined much more broadly than real estate. Property is an all-encompassing term that includes houses, cars, personal items, and most importantly: labor. In modern times some of the most valuable property a person can own is not land, but ideas. This is why we have patent and copyright laws. In fact, for most people, our most valuable property is not the land we own, but ourselves and our ability to work, think, and be productive.

The defining principle of any economic system is how that economic system handles the ownership of property. In the time of Adam, ownership of property was simply undefined. There was so much land that competing claims of ownership were solved by simply moving. The classic example of this type of system in practice was the confrontation between Lot and Abram in Genesis 13.

Lot and Abram were both so wealthy in flocks and herds that when a conflict arose because there was not enough grazing land, Abram simply said to Lot, "Let's not have any quarreling between you and me, or between your herdsmen and mine, for we are brothers. Is not the whole land before you? Let's part company. If you go to the left, I'll go to the right; if you go to the right, I'll go to the left." (Genesis 13:8-9).

Unfortunately, such a solution is not available to solve our quarreling brothers today. We must find another way to get along. The economic system used by Abram and Lot, usually referred to as 
tribalism, was prevalent in the world for many years, essentially until the land ran out. One thinks easily of the tribal nature of native Americans before the Americas were settled by European powers. It is a very convenient system, but simply unavailable as a viable system in today's world.

A second approach to ownership goes by the name of feudalism. In this system, all property is considered to be owned by the sovereign. In other words, the King owned all, including land and labor. The usual arrangement was not for the King to manage these lands directly, but to grant tracts to lords or nobles in exchange for military service or taxes collected from the produce of the land.

Again, the term property was defined broadly, for it did not merely mean land, but also all structures built on the land, and even the peasants who lived on the land. This economic system, prevalent during what is known as the Dark Ages, favored the nobility and kept the masses of peasants tied to their masters. It had its own certain logic, but the times were not called the Dark Ages for nothing.

\section{Mercantilism Emerges}

As society began to advance out of the Dark Ages, several different types of economic systems began to emerge. Three systems predominate today, and each has its own distinct approach to ownership. The three systems are: mercantilism, socialism and capitalism (or free enterprise). Mercantilism is the system that grew out of feudalism. It had its heyday in the 17th and 18th centuries when the new world was being settled and the European powers were seeking colonies.

The fundamental principle of mercantilism was private ownership of property, but this private ownership was conditioned with two caveats. First, all property ownership was the result of a grant from the sovereign. This idea, of course, was a holdover from feudalism, but it was much more loosely applied than during feudal times. The strength of private ownership was much stronger. The sovereign could no longer be so arbitrary in his taking of property from private citizens. The courts and the legislatures would not stand for it. Laws were passed making private property much more private. 
The second condition attached to private ownership was much more important. Under mercantilism, the strength of a country was considered to be the amount of gold it had in its coffers. Therefore, laws were passed regulating business so as much gold as possible passed into the coffers of the King. During the time this idea made a great deal of sense. A King was considered only as strong as his army (and in the case of England, the navy). And to field an army required a great deal of one thing: money. Since the currency of the day was gold, everything had to be done to increase the amount of gold going to the King.

This idea, of course, was one of the reasons for colonies. The colonies would produce the raw materials necessary to fuel the factories of the motherland. These products could then be exported and cause gold to flow into the mother country. In essence, businesses and commerce were heavily regulated so the flow of gold could be managed for the benefit of the sovereign. Many of the laws passed by Parliament that were so offensive to the American colonies were justified under this theory of mercantilism.

Although mercantilism had its heyday several centuries ago, it continues to be practiced today. Although rarely labeled as such, mercantilism is the result of the heavy regulation and restrictions placed on private ownership of property by the large governments of today's society. Usually under the guise of health, safety or environmental requirements, many governments place severe restrictions on the use of property by private individuals. This is especially true with regard to most people's most important asset: labor. If government takes $30 \%$ of your pay in taxes, then you own $70 \%$ of your labor and the government owns $30 \%$. The government then spends $30 \%$ of your income from labor for projects it deems necessary. This is mercantilism.

The remaining two economic systems were deliberately saved for the last part of this essay. The reason? They are the two economic systems that are most debated today. They are the two competing ideologies that govern most of the world today. While mercantilism may be prevalent, it is not really discussed and debated. The polar extremes of capitalism and socialism occupy the primary attention of most economists and theologians. The remainder of this essay will define the distinct difference in property 
rights between the two systems. Other essays will develop other differences.

\section{Capitalism vs. Socialism}

Identifying the primary and fundamental difference between capitalism and socialism is not difficult. Again, the primary difference is in the ownership of property, and the two systems are in diametric opposition on this question. In capitalism, there is private ownership, and in socialism, there is public ownership, or all things are owned in common. This difference is probably best illustrated by a familiar passage in Acts 4. The church had just been established, and in the euphoria that followed Pentecost, many people were coming into the church. When they came, they brought everything they had:

All the believers were one in heart and mind. No one claimed that any of his possessions was his own, but they shared everything they had. With great power the apostles continued to testify to the resurrection of the Lord Jesus, and much grace was upon them all. There were no needy persons among them. For from time to time those who owned lands or houses sold them, brought the money from the sales, and put it at the apostles feet, and it was distributed to anyone as he had need. (Acts 4:32-35)

The twin towers of ownership are clearly demonstrated in this passage. Before entering the fellowship of Christians, the people owned their property privately. In other words, they could use their property as they saw fit. The primary use, of course, was to provide for themselves the necessities of life. After they became Christians, from time to time they sold their property and gave it to the apostles. The property was then no longer private. They gave the property to the apostles who used it to meet the common needs of the body of Christians. This is an example of private vs. public ownership.

While the ownership of property is the cornerstone difference between capitalism and socialism, it is the implications of these two types of ownership that is most interesting. One of these implications is the assumption of individual responsibility. 
In capitalism, since all property is privately owned, each individual must be responsible for his or her own well being. Since government does not own property, or since there is no communal ownership of property, the government or the community does not have the means with which to take care of an individual. Since all property is owned privately, each private individual must take care of himself and his family. This implication of private ownership offends many of those who are socialists. They point out that the poor, the lame, the blind, the hungry, the thirsty, have no one to look to when they are in need and do not have the resources (or property) to take care of themselves.

\section{Socialism and the First Century}

In socialism, there is no private ownership of property, all property is owned communally or in common. Religious socialists sometimes point to Acts 4 as the model socialist community. What they forget is that the Christians in Acts 4 were acting voluntarily, while socialist countries compel the socialist system upon their people. Also, the implication of Acts 4 is that it was only from time to time that houses were liquidated and the money given to the apostles. Faith, repentance and baptism were the conditions upon which one entered the fellowship of Christians. Selling one's house was not one of the conditions.

The most famous quote from Karl Marx succinctly summarizes the socialist ideal, "From each according to his ability, to each according to his needs." In other words, every citizen should contribute to the common fund as he has the ability to work and contribute. Likewise, each should draw from the common fund as he has need.

Before continuing the discussion of the differences between capitalism and socialism, it would perhaps be good to stop and remind ourselves that both capitalism and socialism are merely economic systems designed to do the same thing: allow society to cope with scarcity. Remember: economics is the science of creating a system which will allow society to allocate the available resources among the competing wants and needs of the populace. Neither capitalism nor socialism is God ordained, and one can be a saved believer under either system. 
Capitalism is known by many names. Free enterprise, private enterprise, the market system, the price system or the incentive system are all names for capitalism. The first person to fully describe capitalism fully was Adam Smith (1723-1790). A Scotsman, Smith published his seminal study and explanation of the capitalist system in 1776. The formal title is An Inquiry into the Nature and Causes of the Wealth of Nations in 1776. The shorthand title of the book is The Wealth of Nations. The book really had two primary purposes. First, to refute the mercantilist philosophy of the day and second, to describe the free market system.

Socialism is also a relatively recent economic phenomenon. The person who best described its function was the communist philosopher, Karl Marx. While Marx was an atheist, and it is true that many atheists embrace the socialist philosophy, this should not cause one to reject it too quickly. Many atheists are adherents to the capitalist system as well.

A cursory look at the two systems finds much good to say about socialism. It makes the promise that everyone will be taken care of since the community is responsible for the care and well being of each individual. Capitalism makes no such promise. If a person under capitalism has no property and no private means with which to take care of himself, he must rely on the kindness of strangers to be fed. Certainly government cannot take care of him since government by definition has no property.

While the theory of socialism has much on the surface to commend it, there are some hidden dangers for the adherents of this philosophy. These will be explored in later essays. 


\section{FAMILY THROUGH THE EYES OF AN ECONOMIST}

Ronald Reagan had a favorite joke he liked to tell on economists: "An economist is the only professional who sees something working in practice and then questions in theory whether it can work at all."

As economists we are more often known for using arcane language and unintelligible mathematics than for clear reasoning and simple solutions to current problems. Economists also are usually uncomfortable when dealing with the subject of the family. Families are like snow-flakes, each one is different, and as economists we are much more comfortable with the uniformly cold calculus of price theory than the messy diversity of family life.

To an extent, this essay ignores some of the tougher issues involved with family. This essay ignores the pressing problems of divorce, unfaithful children and unfaithful spouses. This essay is less ambitious. The purpose of this essay is really quite simple: We are to investigate which economic system, capitalism or socialism, is most advantageous to family life and living. To put the purpose in the form of a question: Which system promotes the family and makes family life possible, and which system retards family and makes family life more difficult?

It is assumed here that there are two basic economic systems from which a country can choose when deciding upon the arrangements that will be implemented to cope with the problem of scarcity. These two systems are capitalism and socialism. The outline of this paper is: (1) to highlight briefly a few of the differences between the two systems, and then based on these differences, (2) to describe the effect that each has on the family.

\section{Capitalism and Socialism}

It should be understood that no country exists which is $100 \%$ capitalistic in its economic system. Neither can one find a country which is $100 \%$ socialistic. Certain countries (the United States, Japan, Great Britain) tend toward the capitalistic economic system. Other countries fall in the middle of the continuum. But, while no country is perfectly capitalistic or socialistic, it is useful to study the polar extremes, for by studying extremes one hopes to find which system 
tends to support the family and which system tends to destroy the family.

When I first started writing this essay, the events of the world seemed to point out that there were actually two competing economic systems. However, with the fall of the Soviet Union, and the mad dash from socialism to capitalism by Eastern Europe and Russia, it seems that the only people who still believe in socialism either rule in Cuba or teach in the economics departments of Harvard and Berkeley.

Perhaps the most useful aspect of this essay will be to explain why so many in these formerly socialistic countries wanted so badly to overthrow the system.

There are many things which differentiate between the two economic systems. To catalogue them would be challenging (and perhaps futile), but for our current purposes I will limit myself to three rather obvious and important differences that have the largest impact on the family: The ownership of property, the assumption of responsibility, and the role of government.

The difference between capitalism and socialism perhaps is sharpest on the issue of ownership of property. Under a capitalistic framework property is owned by private individuals. Under a socialistic framework property is owned communally.

The term "property" as used in the above paragraph is interpreted very broadly. Property includes not only land, but also housing, machinery, equipment, factories, tools, clothing, food, and most importantly, labor. Under a pure, $100 \%$ grade A capitalistic system there are no parks (communal ownership of land) or government owned enterprises (the Post Office). All such things are owned privately. Furthermore, it is important to note that private ownership is taken very seriously. The owner may use the property as he sees fit, limited only by his imagination and the caveat that he must not harm another person or another person's property.

In socialistic societies, property is owned communally or all things are owned "in common." In other words, in a nation of 250 million people a factory is not owned by a single person, but each person owns $1 / 250$ millionth of the factory. Of course, this is the 
theory of socialism. In reality the government manages all resources on behalf of the people.

In addition to the issue of ownership of property, capitalism and socialism differ on the issue of responsibility. The question is: Who is responsible for the care, feeding, and general well-being of each member of society?

Under capitalism the answer is each individual is responsible for his own well-being. Government or "society" has no responsibility to care for the individual. That responsibility is his and his alone. If an individual is hungry, other individuals may help the hungry person out of a sense of pity or duty or religious conviction, but society as a whole does not bear any responsibility toward the feeding of the populace.

Under socialism, responsibility for the individual rests with society as a whole (or more specifically, government). Society has the duty to care for the hungry and homeless. Society must provide food, clothing, and shelter to everyone since society has assumed that responsibility.

One must realize that the two issues of ownership and responsibility are mutually reinforcing. If individuals own property, then they have the means to bear the responsibility of caring for themselves. Conversely, if individuals do not own property (except in common) then it is not logical to ask them to care for themselves. They simply do not own the means to do so. Even their labor is owned in common, so they must rely on the graces of society for their needs to be fulfilled.

As a final point in our brief discussion of the differences between capitalism and socialism we must turn to the role of government. As the sole legitimate agent of organized force in society, government must play a role in every system. Differences are highlighted when the functions of government are addressed from a theoretical standpoint.

Under capitalism the role of government is to protect and enforce property rights, but little else. Under capitalism, government is to protect your property from external invasion by foreign armies (national defense), and it is to protect your property from internal harm by bandits and brigands (police protection and courts). Otherwise the government 
leaves economic actlvity up to the spontaneous order created by indwiduals through their voluntary exchange of private property. Government is charged with frugality and the job of administration of justice, but not the administration of resources.

Under socialism, government is charged not only with the administration of justice but also the administration of resources. It should be noted here that we are bypassing the question of whether or not government represents society. In some cases they do, but in many cases they do not. Here we are essentially making the rather heroic assumption that governments in socialistic society represent the wishes of the people in common.

The role of government is to carry out the dictum attributed to Karl Marx: "From each according to his ability, to each according to his needs." In other words, each individual contributes to society (government) as he has the ability to work and produce. Society (government) then distributes the fruits of labor as each individual needs for the comforts of life. This is only the logical result of assuming all forms of property (including labor) are owned in common and society, not the individual, is responsible for individual well-being.

\section{The Family and Capitalism}

Given the above as back-ground we are now ready to turn to the real purpose for this paper. How does all this affect the family? Let me state my thesis boldly and then, hopefully, I can support it. My thesis is this: Capitalism is the only economic system that has an explicit role for the family. It is the only system that can nurture and promote the family. Negatively, let me state my thesis this way: Socialism has no role for the family and will ultimately destroy the family.

While all of the analysis of capitalism has focused on the individual (individual ownership of property and individual responsibility) there should be a realization that this is an incomplete analysis. Under capitalism, each individual owns property, has the responsibility to care for himself, and there is little interference from government. But the analysis cannot rest on the individual, for there are some individuals who are simply incapable of caring for themselves. 
Specifically, who takes care of the children and the elderly? Who takes care of the sick, the invalids and the insane? Capitalist theory as stated above does not account for these things and, therefore, capitalist theory must do one of two things. It must either allow for some governmental responsibility to these individuals or it will assign such responsibility to the family.

Pure capitalistic theory assigns the responsibility for children to the families of the children. The elderly, the invalids and the insane are the responsibility of the families of the elderly, the invalid and the insane. It is only when such an individual has no family that the government must step in and take care of someone who cannot take care of himself. Milton Friedman mentions in one of his books, "The ultimate operative unit in our society is the family, not the individual".

Perhaps a few examples or cases are in order. In the history of the United States there are periods of time where capitalist theory was implemented to a degree approaching purity. During the administrations of the first few presidents the country was sparsely populated over a large amount of land. Few government controls were in place and taxes were almost nonexistent. Thomas Jefferson was able to write, "It may be the pleasure and pride of an American to ask what farmer, what mechanic, what laborer, ever sees a tax gatherer of the United States?" Therefore, government was limited to protecting property but had no revenue to take care of the less fortunate of society.

During this same period of time there was a rise in family values and virtues. In his book on the Civil War entitled Battle Cry of Freedom, the historian James McPherson noted that in the period just prior to the Civil War there was an emergence of the family as a strong and stable centerpiece of American society. Children became the center of the home, and women were no longer required to work just to keep food on the table. Parents lavished love on the children and education became prominent. Many European scholars commented on the healthy nature of American families, perhaps a reaction to some of the hideous childcare practices of Europe recently documented by John Boswell in his book The Kindness of Strangers.

The point of this being that since early American governments refused to accept any responsibility for 
the less fortunate, fathers and families had to do so. The serendipity of capitalism is that it provides the prosperity that allows families to care for their own.

\section{The Family and Socialism}

While the pure theory of capitalism assigns a certain role to families, when the same questions are asked of socialism, the answers are much different. Who takes care of those who can't take care of themselves under socialist society? The answer has really already been given. It is society (or government) that takes care of everyone's needs. What role then is there for the family? In theory, there is none.

The issue of socialism and the family is brought into sharper focus when one analyzes one responsibility which is very dear to our hearts: Who is responsible for the children? Most societies assume that parents are to care for and nurture their children, although recent scholarship has pointed to some rather gruesome practices in ancient times. In terms of the current analysis, children are the private property of their parents and in capitalistic society, parents are responsible for the care of their children with little, if any, government interference.

In socialism, all property is owned in common, and this includes children. In the pure theory of socialism, parents do not assume responsibility for children since society is responsible for taking care of all needs. While this analysis and these examples may seem to present a fairly extreme conclusion, it is one that is reinforced by writers and thinkers on socialist theory down through the ages. The most blatant and uncompromising statement of the results of pure socialist theory was made by Friedreich Engels, the mentor and collaborator of Karl Marx:

With the transfer of the means of production into common ownership, the single family ceases to be the economic unit of society. Private housekeeping is transformed into a social industry. The care and education of the children becomes a public affair; society looks after all children alike, whether they are legitimate or not...

The family is simply irrelevant to the proper functioning of a pure socialistic society. It is essential to the proper functioning of a pure capitalistic society. 


\section{Creeping Socialism}

I would assume that there has been very little so far in this essay that most readers would disagree with. In order to breathe a little controversy into the article, let's take an example of a socialistic program that has widespread support in the United States. I am speaking of Social Security.

The first Social Security benefit was received by Ida Fuller of Ludlow, Vermont in 1941. Since that time the system has been expanded so that almost every American age 65 and over receives a check from the government, and almost everyone under 65 pays Social Security taxes.

From a purely economic viewpoint, the program is entirely socialistic. It violates all three tenants of the capitalistic system. It moves private property into the public domain by taking part of a persons labor and instead of this labor being owned by the individual, it is owned by everyone in common. It causes people not to be responsible for themselves in their old age since government pays their benefits. It also causes massive government intervention into the lives of individuals and their families. So using the three criteria established in the first part of this essay, there is no doubt that Social Security is a socialistic, not a capitalistic system.

This program is politically sacrosanct, but the question asked here is: How does this effect the family? Are family bonds weakened or strengthened because of Social Security?

In theory and in practice there is little doubt that the family is weakened by Social Security, especially between generations of the family. Before Social Security was enacted children set aside part of their income for the care of parents. Forty years ago, it was not uncommon to have aged parents living in the same house as their children. The children had to assume the responsibility for the care of their aged parents... a role that now is often abdicated by the children since "Social Security will take care of them." Rather than intergenerational families being the norm, they are now the exception. There is no doubt that Social Security causes intergenerational resentment rather than intergenerational care and respect.

Whether or not it is beneficial to have aged parents living with children is a social and moral question. As 
an economist I am only pointing out that a socialistictype program has broken or at least weakened the responsibility of the family for some of its members.

I have entitled a recent paper The Pure Theory of the Family in Capitalistic and Socialistic Economic Systems. The emphasis is on "Pure" for no society is all capitalistic or socialistic. But by studying the pure theory we can view everyday policy alternatives in a different light. If a policy moves us toward capitalism then it is a pro-family policy. If it moves us in the other direction, then it is anti-family. 


\section{THE ECONOMICS OF SIN}

The subject of $\sin$ is not a popular subject. Yet our $\sin$ is ever before us. We cannot escape it. It is the realization of sinfulness in our lives that forces us to call on the grace of God to save our souls from hell.

Paul tells us that "all have sinned and fall short of the glory of God." (Romans 3:23). Jews and Gentiles, slave and free, man or woman, young or old, it makes no difference. No one, on his own, can escape the clutches of sin. Without Christ we would be condemned to a life of eternal suffering because of our $\sin$.

So the reality of $\sin$ is there. It's a messy subject. It's a subject that hits too close to home. We can't have our pride if we continue dwell on our sin.

What does the subject of sin have to do with economics? One obvious answer is that many of our sins have to do with dishonesty over money. In a familiar passage, Paul said ". . the love of money is the root of all kinds of evil. Some people, eager for money, have wandered from the faith and pierced themselves with many griefs." (I Timothy 6:10) When Christ was on this earth, his answers to the rich ruler caused the man to be very sad, "because he was a man of great wealth." (Luke 18:23)

One can be wealthy and still serve the Lord. Several examples from the Old Testament (Abraham, Job, David) show us that the wealthy are not automatically excluded from the righteous life. The New Testament seems to warn us so very carefully about the dangers of wealth rather than condemning wealth itself.

The subject of personal money management is an important one. If a Christian can do it well, he or she can avoid many of the heartaches and tensions that accompany life on an imperfect planet. But personal money management is not the primary subject of this essay. I have a much broader view in mind. What I hope to accomplish is to show that the capitalist economic system, rather than the socialist system, is more consistent with the New Testament doctrine of $\sin$.

I am assuming that most of the readers of this article will know more about sin than economics. I 
am assuming that most of the readers have a more unified view of sin than economic systems. The first few paragraphs of this essay in essence summarized the New Testament doctrine of sin: All have sinned. All stand in need of God's grace. All must accept Christ or be eternally condemned because of sin. And even after accepting Christ and even if we are trying to live for Him, we are still going to sin. But we remain in Him, despite our sin, because His blood continually wipes away our sin.

\section{The Moral Link}

But what does this have to do with capitalism and socialism? It is really very simple. All have sinned; all will continue to sin even after accepting Christ. No one must ever be allowed to have too much power. Even if a good man, a Christian man, a man who wants to use his power for good, is granted power, he will sin and make mistakes and do things that will hurt the people he has under his power. Let me first explain this idea with regard to government, then the application will continue with regard to economic systems.

One of the foundation principles of the government of the United States is separation of powers. This is the reason for having three branches of government. The legislative has the power to pass laws, but the executive has veto power over the legislative. The legislative can override the veto, but once a law is enacted, the power of legal interpretation rests with the judiciary. While the executive is commander-inchief of the armed forces, only the Congress can declare war. While the judiciary is responsible for judgement of criminality, only the executive can bring charges against criminals.

The question arises as to why the founding fathers of the United States formed government around the separation of powers. Quite simply, they had a common understanding about the power of government and the doctrine of sin. They knew that if one person were granted too much power, it could and probably would be used for evil purposes. One does not have to think too long to remember examples of evil uses of governmental power.

Government is a powerful entity. It is the sole repository of legal, organized force in society. No other entity, no other person can force you to do anything against your will except the government. 
Take for example the payment of debts. If you have a car loan at a bank, and you are behind on payments, the bank can call you expressing a desire for payment. The loan officer can come to see you at work or at your home or while you are just sitting in your car, but the loan officer cannot force you to pay him back. To get the authority to garnish wages or reposess your car, he must go to a representative of the government (the judge) and get legal authority to force payment or repossession. The government is the sole owner of the ability and right to force people to do things against their will.

Two other examples of government's ability to force individuals to do things are the draft and taxes. We are fortunate that the draft does not exist today, but some of us can remember a time when all young men were forced to sign up for the draft at age 18. If your country called, then you either went into the armed forces or you went to jail (conscientious objectors excepted, although the draft board sat in judgement on who was and who was not a true conscientious objector). This ability to force someone into a particular occupation is the exclusive right of the government. No other employer can compel employment.

The payment of taxes is another excellent example of the coercive power of government. If you do not pay your light bill, the power company simply discontinues service. If you do not pay your taxes, the government does not discontinue governmental services to you, it garnishes your wages or your home or your furniture or your car or any other property you may have.

Having pointed out the problems with governmental power, it may be necessary to say that government is a necessity to civilized society. If government were not given coercive power, anarchy would reign, and anarchy is nothing more that the rule of the strong at the expense of the weak.

So while the coercive power of government is very strong, it is a necessity. What must be done is to try to construct government to make sure there are checks and balances in the use of this power. The solution proposed by the founding fathers was the establishment of the three branches of government. The three branches are there to make sure no one individual can obtain control over all three branches at the same time. 
If someone were able to do so, such would be the stuff of dictatorship. Even if the dictator were a Christian, a true follower of Christ trying to use his power in a good and honest way, this Christian would still sin and make mistakes that would harm other people. We should also remember that power tends to attract the corrupt rather than the Christian, so it is only a matter of time until dictatorial powers reside in the hands of a non-benevolent despot. So the doctrine of sin instructs us to disperse power. The application to economic systems (capitalism vs. socialism) remains for our discussion.

\section{The Concentration of Power}

The socialistic economic system, based on public ownership of property, tends to concentrate power. The basic idea of socialism is the same idea as presented in Acts 4. The early Christians would sell their property from time to time, give the proceeds to the apostles, and then the apostles would distribute to those who had needs. Karl Marx encapsulated this idea with the phrase, "From each according to his ability, to each according to his needs." In other words, under socialism, each person contributes to the common pot of funds as he or she has the ability to contribute and then each person receives from the common pot as he or she has need.

The real question becomes: Who controls the common pot? If the person in control of the common pot is Peter or John, I would feel pretty safe about my contribution. But when the controller of the common pot is a politician; an unknown, faceless bureaucrat; or, really, anyone else, then I feel much less safe about my contribution.

In a country of any size, the common pot would be a very large amount, and Biblical warnings about temptation and wealth would be especially relevant. Indeed, one needs only to read the newspapers for a few days to hear of another bureaucrat stealing from our common funds. Socialism is a beautiful theory, but it's application runs headlong into problems caused by sin.

Capitalism is not immune to sin either. Visit any successful capitalist city and the city wears its sin like a scarlet letter. Neon signs boast of sex, liquor and perversity readily available if one will only meet the entrepreneur's price. The drab grey of socialist cities appeal to those who like their sin suppressed and 
hidden. But suppressing sin behind monolithic government buildings does not eliminate it. It only drives $\sin$ underground. Capitalism does not eliminate sin. Neither does socialism. Capitalism only requires an individual to use his own money in order to $\sin$.

The foundation of the capitalistic system is the private ownership of property. Each individual owns his own labor, ideas, and any other physical property that is recognized as his. Economic growth occurs through the voluntary exchange of private property. In capitalism, no one (except government) can force you to give up any of your property. The only way you will give up your property is if someone will exchange their property for your property. Take, for example, when you buy a hamburger and a Coke for lunch. You are taking about $\$ 3.00$ of your private property and exchanging it for someone else's property (the hamburger and Coke).

No one forces the exchange on either side. It is mutually beneficial or it would not occur. This system of mutually beneficial exchange of private property is the essence of the capitalistic system. No coercion is allowed. This system has the benefit not only of the absence of coercion, but it also disperses economic power. Personal fortunes may seem large in the United States, but even the most wealthy individual generates only a small fraction of total national income.

Some corporations are very large, but even the largest generate only a small fraction of Gross National Product. And the wealth of these individuals and corporations is subject to their continued ability to meet the needs of their customers. If the customer's needs are not met, then the customers will take their business elsewhere.

Economic power in the United States is not concentrated in the hands of a few, it is distributed to anyone who has the ability to enter into mutually beneficial exchange. "Power corrupts and absolute power corrupts absolutely," is the famous saying attributed most often to Acton. The source of the corruption is sin. A society would do well to make sure that government power stays divided through a separation of power, and also to make sure that economic power stays divided through capitalism. 


\section{IN THE IMAGE OF GOD: FREEDOM}

In Genesis 1:26-27, the Bible states: "So God said, 'Let us make man in our image, in our likeness, and let them rule over the fish of the sea and the birds of the air, over the livestock, over all the earth, and over all the creatures that move along the ground.' So God created man in his own image, in the image of God he created him; male and female he created them."

The creation of man in God's own image does not mean that God has two arms, two legs, one nose and one mouth. God is a spirit, and spirits need not take earthly form. God could appear in the form of a man, as Jesus did, but God could also appear as a burning bush, a cloud in the wilderness, or a chariot of fire. Certainly we know from descriptions of God in Genesis 1:2 and in the book of Revelation that God should not be limited to any one physical description.

If God is not limited to a certain physical description as men and women are so limited, what does it mean that man is created in the image of God? One clear understanding we may have is that there are certain characteristics of God that are also found in man. One of these characteristics is the ability to choose.

God had the ability to create man or not create man. He had the ability to create the Garden of Eden, and $\mathrm{He}$ had the ability to destroy it. God had the ability to destroy the earth by water, and $\mathrm{He}$ has the ability to promise not to do it again. God is free to choose to do as $\mathrm{He}$ sees fit.

God could have chosen to create man so that man did not have the ability to choose. But God did not take that course of action. God decided to give man one of God's most important traits: the ability to choose. Therefore, as men and women created in God's image, we have a wide range of choices set before us. Probably the most important choice we have is the ability to choose whether or not to call on Jesus as our Lord and accept the salvation that is offered through him. It is this ability to make conscious choices that most separates man from the animals and makes man most like God.

Most people regard it as a mark of maturity when a child is able to exercise intelligently and wisely the ability to choose. Poor choices are the mark of an 
immature, uneducated, hedonistic, and ungrateful child. Wise choices are the mark of a mature individual who is appreciative the life the Lord has given to him.

\section{Trade-offs and Choices}

Some of the choices we make have eternal consequences, as in our decision whether or not to serve the Lord. Some of the choices we make have very long and lasting consequences here on earth, as in our decision about whom to marry. Some of the choices we make have significant consequences on other people, as in the decisions we make on how to discipline our children. Fortunately, some choices have hardly any consequences at all, as in the case of whether or not to have a hamburger or a cheeseburger for lunch. But these are all personal choices, and whatever personal choices we make, we must live with the consequences. Choices have consequences, and we must accept the responsibility for our choices.

Many people spend a great deal of time and effort trying to avoid responsibility for the consequences of their choices. Politics is probably the most glaring example of this. Politicians are prone to obfuscation in order to avoid being blamed for the wrong consequences of their actions. If the budget is unbalanced, the President blames the Congress, and the Congress blames the President. If people are killed in a stampede prior to a basketball game involving rap stars, the organizer blames the police, the police blame the organizers, and it would be comical if it were not so serious to see the lengths to which people will go to avoid being blamed for problems.

Those of us who have children understand very well how far children will go to absolve themselves of responsibility. Bill Cosby once said that no one is really a parent who has only one child. For if you have only one child, and a vase is broken, you automatically know who did it. But if you have two children, and a vase is broken, it takes the wisdom of Solomon to judge the guilty party among all the accusations and pleadings.

But as mature adults, we know that if we are allowed to make our own choices, we must accept responsibility for the consequences of our choices. This is certainly a Biblical principle. II Corinthians 5:10 states: 
For we must all appear before the judgement seat of Christ, that each one may receive what is due him for the things done while in the body, whether good or bad.

\section{Economic Application}

As has been stated earlier in this series, salvation is something that transcends economics. Salvation is possible under capitalism or socialism, under wealth or poverty, under political freedom or political tyranny. But having said and understood the transcendence of salvation over economics, it is not wise to allow nonbelievers to establish any economic system they deem appropriate.

Quite the opposite. As Christians we should be pro-active, using our knowledge of the Bible and Biblical principles to assist in establishing the economic system which is most consistent with Christian principles. If a fundamental characteristic of man created in the image of God is the ability to choose, then I propose that the most appropriate choice of economic system for a country is the one which allows men and women the most choice possible (with the caveat that one must accept the responsibility for the consequences of one's choices).

If one accepts this thesis, it follows that we should analyze the available economic structures and then implement the one which allows the most freedom of choice, since God is a God of freedom of choice. Let us therefore quickly summarize the fundamental characteristics of a capitalistic economy vs. a socialistic economy and our choice between the two should then be obvious.

\section{Socialism Revisited}

Socialism is the economic system which is characterized by communal ownership of property and communal responsibility for the welfare of the individual. By communal ownership of property it is meant that no individual can lay claim to land, buildings, equipment or even their own labor. All of these things are owned in common, and in the practice of socialism, all of these things are managed by the state on behalf of the people.

It is also true under socialism that no individual is responsible for taking care of his personal needs. All of these things are provided for the individual by 
the state (again acting on behalf of the people). To resurrect once more the summary dictum of Karl Marx: "From each according to his ability, to each according to his needs." In other words, each individual will contribute to the common good as he has the ability to work and produce; then, each individual will receive from the common coffers as he has need.

It should be clear from the above two paragraphs that socialism violates the principle of freedom of choice and individual responsibility. According to socialist doctrine, each individual receives according to his needs. The crushing problem of socialism is the determination of needs. Rather than each individual choosing to accommodate his or her needs based on his or her own values and judgements, under socialism someone else is determining these needs and making the decision of what goods and services to produce.

Additionally, socialism absolves the individual from all personal responsibility. Socialist doctrine states that each individual will receive what he or she needs. It does not matter whether or not the individual wastes his time through a lack of work effort on the job, he still receives according to his need.

The conclusion is rather obvious, socialism is not consistent with the doctrine of freedom of choice and the acceptance of responsibility for the consequences of your choices.

\section{Capitalism and the Individual}

The capitalistic economic system is the one which is characterized by private property and an individual's taking care of his or her own personal welfare. By private property it is meant that each individual can lay claim to a piece of land, or a building, or some equipment, or most importantly, his own labor, and use that property as he sees fit, only given the restriction that his use of his private property does not harm some other individual or cause damage to some other individual's private property.

If the principle of private property is taken seriously, the government or community does not have the means with which to take care of any person. Under socialism there is communal ownership, not private ownership, so the individual does not have the means to take responsibility for his own well being. With private ownership, and no communal ownership, the 
community does not have the means to take responsibility for the well being of the individual.

It should now be clear that capitalism, with its system of private property rights and individual responsibility, is more consistent with the Biblical doctrine of freedom of choice and individual responsibility. Again, salvation transcends the economic system of any country, but a country can ignore these Biblical doctrines only at its own peril.

The ENTREPRENEUR is a quarterly journal and newsletter addressing contemporary economic issues from a moral perspective. One may not agree with every word printed in the ENTREPRENEUR series, nor should feel he needs to do so. It is hoped that the reader will think about the points laid out in the publication, and then decide for himself. 




\section{ABOUT THE AUTHOR}

Dr. David Tucker is Dean of the School of Business and Professor of Economics at Harding University in Searcy, Arkansas. He is also Director of the Walton Scholarship Program for Central American Students.

Author of numerous publications and articles, Dr. Tucker's essays on Christianity and economics have been published in the Gospel Advocate, Journal of Private Enterprise, and Journal of Economics and Finance. They will soon be translated into Spanish in order to be published in La Voz Eterna, a publication sent to Christians throughout Mexico, Central and South America.

Dr. Tucker won a $\$ 1,500$ prize in 1986 from the Mont Pelerin Society for his essay entitled, "The Economics and Philosophy of Liberty." The essay was presented to the bi-annual convention of the Mont Pelerin Society in St. Vincent, Italy, and has been reprinted in several subsequent publications.

Dr. Tucker was also the recipient in 1988 of the $\$ 7,500$ Leavey Award for Excellence in Private Enterprise Education for his work with students from Central America. The Leavey Award is given by the Freedoms Foundation at Valley Forge, Pennsylvania, each year to innovative programs that promote an understanding of free enterprise and democracy.

Also active in community affairs, Dr. Tucker is a pastPresident of United Way of White County and the Kiwanis Club of Searcy. He is currently the Treasurer of the Searcy Boys Baseball Committee and is vice-president of the Newhope Specialized Industries Board of Directors.

Dr. Tucker received his BA degree in accounting and economics from Harding University in 1977 . He worked for two years with Arthur Andersen \& Co. in Dallas, Texas, and earned his CPA from the state of Texas in 1979. He received his MA in economics from Georgetown University in 1981, and his Ph.D. in economics from the University of Arkansas in 1987.

Married to Renee East Tucker, they have two children-Peyton and Kinsey. 


$$
\begin{aligned}
& \text { 焉㭬 } \\
& \text { Ш } \\
& x \\
& \text { N5 } \\
& N \\
& \text { a : 'T } \\
& \text { 先 } \\
& \text { (D) }
\end{aligned}
$$

